\title{
Efficacy and efficiency of poultry carcass composting using different mechanical mixing equipment for avian influenza outbreaks
}

\author{
Jennifer Elizabeth Keaten ${ }^{1}$ and Mark Hutchinson ${ }^{2}$ \\ 1. College of Public Health, University of Iowa, 23 Holden Hills, Bridgton, ME 04009, USA; 2. University of Maine \\ Cooperative Extension, Libby Hall Orono, Maine 04469, USA. \\ Corresponding author: Jennifer Elizabeth Keaten, e-mail: haec.puella@gmail.com, \\ Co-author: $\mathrm{MH}$ : mhutch@maine.edu \\ Received: 23-02-2017, Accepted: 28-04-2017, Published online: 27-05-2017
}

doi: 10.14202/IJOH.2017.19-27 How to cite this article: Keaten JE, Hutchinson M. Efficacy and efficiency of poultry carcass composting using different mechanical mixing equipment for avian influenza outbreaks. Int J One Health 2017;3:19-27.

\begin{abstract}
Background and Aim: Avian influenza (AI) is a viral disease that caused the largest animal disease outbreak in the history of US agriculture. There are several disposal methods of AI infected poultry carcasses available in the US, which include on-site burial, landfill, incineration, rendering, and composting. Of these methods, composting is the most environmentally friendly and poses a low risk for biosecurity. The United States Department of Agriculture (USDA) has developed a comprehensive plan for composting AI infected carcasses. The current protocols have the potential for areas of anaerobic pockets within the windrow due to inadequate mixing and the large carcass size of whole birds. This could lead to ineffective virus neutralization or prolonged composting times and higher resource costs. The purpose of this project was to determine if using a horizontal mixer (HM) wagon to mix composting ingredients or a vertical mixer (VM) wagon to mix and cut up the compositing ingredients is an economical and timely means to accelerate the tissue break-down and obtain optimal temperatures for poultry carcass composting during an AI outbreak.
\end{abstract}

Materials and Methods: A replicated trial with three treatments, HM, conventional layering (CL) and VM, and three replications was initiated at the Compost Research and Education Center part of the University of Maine Forest and Agricultural Experimental Station called High Moor Farm. Daily temperatures and screened core sample weights (screen weights) on day 0,16 , and 30 were recorded for each of the compost piles. The time to build each replication was recorded and used to help calculate the cost of each method. Data on equipment, carbon material and labor costs were collected from private contractors from the 2014 to 2016 highly pathogenic AI (HPAI) outbreak and used to compare costs between methods.

Results: All treatment methods reached USDA protocol temperatures to neutralize the HPAI virus. Screen weights for both the VM and HM treatments were lower than the CL treatment. Screen weights decreased significantly from day 0 to day 16 for the VM and HM treatments with no significant change from day 16 to day 30 . When comparing costs, the mixer wagon methods were the more cost effective than the CL method when using high volume equipment.

Conclusion: The data from this study support the use of a mixer wagon to reduce particle size and mix ingredients for more timely and effective composting of poultry carcasses.

Keywords: carcass management, compost, high pathogenic avian influenza, poultry.

\section{Introduction}

Avian influenza (AI), also known as bird flu, is a viral disease of birds. While waterfowl are the primary carriers of AI, the virus can spread to domestic poultry and cause widespread outbreaks [1]. AI is from a family of segmented negative-sense RNA viruses called Orthomyxoviridae. The overall structure of the virus includes a lipid membrane derived from the host's cell with three membrane proteins including hemagglutinin (HA) and neuraminidase (NA), as well as a matrix two proteins. The surface proteins HA and NA are the

Copyright: Keaten and Hutchinson. This article is an open access article distributed under the terms of the Creative Commons Attribution 4.0 International License (http://creativecommons.org/ licenses/ by/4.0/), which permits unrestricted use, distribution, and reproduction in any medium, provided you give appropriate credit to the original author(s) and the source, provide a link to the Creative Commons license, and indicate if changes were made. The Creative Commons Public Domain Dedication waiver (http:// creativecommons.org/ publicdomain/zero/1.0/) applies to the data made available in this article, unless otherwise stated. most variable in amino acid sequence and are used to name subtypes of the virus. The surface protein HA has 16 known subtypes, while NA has nine known subtypes [2]. These different HA and NA sequences can combine to create many different subtypes of influenza which are constantly changing [3]. Subtypes of AI can cause a wide range of clinical signs and are classified as either low pathogenic AI (LPAI) or high pathogenic AI (HPAI). Most subtypes of AI are LPAI, which cause mild clinical signs in domestic poultry and can even go undetected without surveillance. At present, only viruses with either the $\mathrm{H} 5$ or $\mathrm{H} 7 \mathrm{HA}$ subtype, such as $\mathrm{H} 5 \mathrm{~N} 1$ or $\mathrm{H} 7 \mathrm{~N} 9$, appear to have the highly pathogenic phenotype, which can cause severe clinical signs and up to $100 \%$ mortality in $48 \mathrm{~h}[1,3]$. While not all $\mathrm{H} 5$ or $\mathrm{H} 7$ subtypes are highly pathogenic, they can sometimes mutate into HPAI [3].

Changes in influenza subtypes occur by either antigenic drift or antigenic shift. Antigenic drift is when small changes or mutations occur in the virus 
strain. This happens commonly and quickly due to inefficiency in viral replication and mistakes made in transcription of the negative sense RNA into mRNA [2]. Antigenic shift is when two influenza viruses from different species combine or trade genes, known as viral reassortment, creating a new virus that is very different from the parent subtypes. Antigenic shift results in significantly reduced natural immunity to the virus and can spread rapidly causing a pandemic [3]. The ability of the influenza virus to change quickly due to these two mechanisms allows the virus to adapt to new hosts and environments. While no known sustained transmission from person to person has occurred with AI, at least one case was reported of probable human to human transmission in 2004 in Thailand [4]. An AI pandemic could occur in people if a new HPAI subtype emerges, via antigenic drift or shift, that not only infects humans but also transmits easily from human to human. Antigenic shift could occur if a human was infected with a human influenza and an AI virus at the same time and their genes reassorted, creating a new virus. This same process could occur in swine infected with both avian and human influenza simultaneously [5]. The longer people are exposed to AI the more likely antigenic shift could occur.

AI can have a significant impact on human health, food security, food safety, and international trade. LPAI viruses do not typically infect humans, whereas some HPAI viruses, such as H5N1 and H7N9, can infect humans and are often fatal. Most infections in people are associated with direct contact with infected poultry [1]. The first human infection was recorded in 1997 in an HPAI outbreak in Hong Kong, China, resulting in 18 hospitalized cases and six fatalities [1]. Since then, the virus has spread from Asia to Europe and Africa and has become endemic in some countries resulting in millions of poultry infections, several hundred human cases, many human deaths, and a significant negative impact on global trade [1]. From 2003 to 2016, the World Health Organization recorded 856 infections of $\mathrm{H} 5 \mathrm{~N} 1$ in people, resulting in 452 deaths worldwide [6]. In addition to the direct impact to humans with viral infection, an outbreak of AI in domestic poultry can have a devastating impact on food security as poultry products are an economical source of protein for many countries. While no cases have been recorded from consumption of properly prepared food, some customs put people at risk when preparing food as well. Besides prevention of AI with biosecurity measures, an effective control and eradication program must be implemented to prevent AI from becoming endemic in the domestic poultry population.

In the US, poultry and egg sales account for $11 \%$ of the total US agricultural sales and was a $\$ 42.8$ billion industry in 2012 [7]. According to the United States Department of Agriculture (USDA) Economic Research Service, the US is the world's largest poultry producer and is the second largest exporter of poultry meat [8]. While no cases of AI have been reported in people in the US to date [6], there have been previous HPAI outbreaks in 1924, 1983, 2004 and one recently in 2014-2016, as well as several LPAI outbreaks in domestic poultry. Due to its immense implications on food security, trade and human health, US policy is to eliminate any LPAI of $\mathrm{H} 5$ or H7 phenotype or HPAI outbreaks in domestic poultry.

The most recent HPAI outbreak in the US in 2014-2016 placed significant stress on the agricultural economy and cost the country billions of dollars. It was the largest animal health disaster in the US affecting 211 commercial and 21 backyard flocks throughout 21 states and resulted in the loss of approximately 7.5 million turkeys and 42.1 million egg layer and pullet chickens $[9,10]$. Iowa and Minnesota were the hardest hit with a loss of 32 million birds in Iowa (95\% chickens) and 9 million birds in Minnesota (54\% Turkeys) [10]. An estimated $\$ 1.6$ billion in Turkey and laying hen losses and $\$ 3.3$ billion in economy-wide losses occurred due to the outbreak [11]. In addition, 18 US trading partners imposed bans on shipments of all US poultry and products, including China, Russia, and South Korea (3 of the top 10 destinations for US poultry meat) and 38 trading partners imposed partial or regional bans [11]. In total, $\$ 879$ million was spent by the federal government in the clean-up effort with $\$ 610$ million for depopulation, cleaning and disinfecting, along with $\$ 200$ million for market value indemnification of birds and the remainder for overtime, travel, and supplies and fall planning costs [9]. Despite the high costs associated with eradication, due to the implications of HPAI on food safety, security, trade, and human health, there is a significant economic benefit to timely and efficient response to depopulation and clean up [9].

There are several disposal methods of poultry carcasses available in the US. It is important that the disposal of choice be timely, cost-effective, biosecure, environmentally friendly and have a positive public perception. Disposal options include on-site burial, landfill, incineration, rendering, and composting. In the past, on-site burial was the most common method of disposal, but concerns with groundwater contamination and public perception caused it to fall out of favor $[12,13]$. It also raises concerns about prolonged survival of the virus and slow decomposition of the carcasses [14]. Landfill burial was the primary method used for the 2002 LPAI outbreak in Shenandoah Valley, Virginia, but was associated with high transportation fees as well as biosecurity risks with the removal of the carcasses from the site as well as high tipping fees ranging from $\$ 45$ to $\$ 140$ a ton [12]. Groundwater contamination is also a concern with landfill disposal [12]. Incineration comes with high fuel costs, concerns for air pollution and smoke complaints, high transportation costs and biosecurity concerns with moving the infected carcasses off-site to 
the incinerator [12]. Rendering is another option, but due to biosecurity concerns, few rendering facilities will take infected carcasses [12]. Finally, composting is a means of virus neutralization and was used during the 2002 Shenandoah Valley LPAI outbreak when concerns about ground contamination, pollution, and biosecurity were rising with the other methods [12]. Of all these methods, composting is the most environmentally friendly of the options and poses the lowest risk for biosecurity.

Composting is a biological process that breaks down organic waste, by way of thermophilic, aerobic organisms, into a stable product that is used as a soil conditioner. Composting has been shown to be an effective means for virus neutralization in AI outbreaks and is now considered one of the preferred methods in the US [15-17]. According to a study in 2003, the AI virus in manure is neutralized within $15 \mathrm{~min}$ at $56^{\circ} \mathrm{C}$ $\left(133^{\circ} \mathrm{F}\right), 24 \mathrm{~h}$ at $30-37^{\circ} \mathrm{C}\left(86-99^{\circ} \mathrm{F}\right)$ and 2 days at ambient temperatures of $15-20^{\circ} \mathrm{C}\left(59-68^{\circ} \mathrm{F}\right)$ [18]. Another study in 2006 showed virus inactivation after $24 \mathrm{~h}$ at $25^{\circ} \mathrm{C}\left(77^{\circ} \mathrm{F}\right)$ in manure [19]. Temperatures achieved during active composting are more than sufficient to quickly inactivate the virus $[20,21]$. While temperature is crucial in killing of the virus, exposure to the compost ingredients is also important in fast neutralization $[22,23]$. In addition, in a study by Glanville et al. [22], biosecurity was demonstrated to be highly effective when the compost piles were capped with sufficient non-infected carbon material. Due to its low transportation costs and the creation of a usable, marketable end-product as a soil amendment, composting is the most cost-effective means of disposal as well as the most environmentally sound and biosecure and carries a positive public perception $[15,17]$.

During the 2002 LPAI outbreak in Shenandoah Valley, Virginia, improper construction of windrows raised concern that larger carcasses, such as market weight turkeys, could not be effectively composted. However, in 2004, during an outbreak on the Delmarva Peninsula in Pennsylvania, composting was successfully used with 5-pound broilers to control the spread of the virus [24]. This led to research in 2004 in Virginia with 40-pound market weight turkeys that confirmed composting is successful if done properly $[15,17]$. The Virginia research also showed that crushing, shredding, or tilling of the carcasses can speed the degradation and optimal temperatures by opening the carcasses and releasing and distributing moisture, increasing surface area to volume ratio, and exposing the bones to decomposition. Temperatures reached $140^{\circ} \mathrm{F}$ within 5 days for crushed carcasses and 16 days for whole carcasses. Furthermore, whole birds tended to roll off the piles more, necessitating more labor to replace them in the pile and more carbon material to cover them [15].

At an Iowa layer operation infected with HPAI in 2015, particle reduction size and mixing of carcasses and carbon material was successfully utilized to compost more than 4 million birds. Initially, a horizontal tub grinder was used to grind up carcasses and carbon material. Then, a tebbe manure spreader, with the horizontal spinners off and at a very low discharge speed, created the compost windrows [25]. The tub grinder was used inside of a manure shed and loaded with birds, corn stover, and wood chips and the mixture was loaded into the manure spreaders and taken to the outdoor composting site. During the height of the operation, when the crew was running most efficiently, a crew of 3-4 five yard ${ }^{3}$ loaders, 1 tub grinder, 1 tractor with a 42 yard $^{3}$ tebbe manure spreader and 1 tractor with a 32 yard $^{3}$ tebbe manure spreader could process approximately 350,000 birds in $12-13 \mathrm{~h}$ [25].

The USDA has developed a comprehensive plan for composting AI infected carcasses titled "Mortality Composting Protocol for AI-Infected Flocks" [26]. This plan requires that all carcasses, feed and litter be composted in windrows for 28 days before release of the material from the site. The windrows must reach an average of $131^{\circ} \mathrm{F}$ for 3 consecutive days during the first 2 weeks, at which point, the windrows are turned and then must reach $131^{\circ} \mathrm{F}$ for 3 consecutive days during a second 2-week period. Alternatively, if $131^{\circ} \mathrm{F}$ is not reached, $110^{\circ} \mathrm{F}$ for 10 consecutive days during both 2 week periods is acceptable. The provided protocols do not currently support the use of mechanical equipment that aggressively mixes or grinds due to concern with virus aerosolization. The current protocols have the potential for areas of anaerobic pockets within the windrow due to inadequate mixing and large carcass size of whole birds. This could lead to ineffective virus neutralization or prolonged composting times and higher resource costs.

If an economical and safe means for carcass size reduction and mixing can be accomplished, then, in theory, the decomposition and pile temperatures will be more uniform, and therefore, virus inactivation and carcass degradation will occur faster. If it is established that carcass reduction and mixing is more effective at composting carcasses, then the question must also be addressed if there are an economical and time effective means to accomplish this in a large outbreak situation. The purpose of this project was to determine if using a horizontal mixer (HM) wagon to mix composting ingredients or a vertical mixer (VM) wagon to mix and cut up the compositing ingredients is an economical and timely means to improve and accelerate tissue break-down and obtain optimal temperatures for poultry carcass composting during an AI outbreak.

\section{Materials and Methods}

\section{Ethical approval}

There was no need to obtain the ethical approval as study was based on compost only and no live animals were involved in the study.

\section{Layer hens carcass composting trials}

On August $8^{\text {th }}, 2016$, a replicated trial with two treatments, HM and conventional layering (CL), 
and three replications was initiated at the Compost Research and Education Center part of the University of Maine Forest and Agricultural Experimental Station called High Moor Farm. The six piles were oriented in a south to north direction on a paved surface. All feedstocks were handled by a tractor loader with an approximately $3 / 4$ yard $^{3}$ bucket. An 18 -inch base layer of used horse bedding, moistened slightly with water, approximately 6 feet wide and 30 feet long was formed for each treatment. Feedstocks for each replication were used horse bedding, wood chips, poultry manure, and chicken carcasses. The average number of birds per bucket load was 254 birds, which was determined by counting 12 bucket loads of birds on three different occasions.

Pile formation was different for each treatment. For the HM treatment one bucket of used horse bedding, one bucket of wood chips, one bucket of poultry manure, one bucket of chicken carcasses, and 100 gallons of water were loaded in the HM (Kuhn Knight Model 3042) and allowed to mix. Mixing occurred continuously as feedstocks were added. This mixture was discharged to the top of the 18-inch base layer of used horse bedding. For the CL treatment, feedstocks were layered directly onto the base layer in the following order; a $1 \frac{2}{2}$ bucket of chicken carcasses, 1 bucket of used horse bedding, 1 bucket of poultry manure, 1 bucket of wood chips, another $1 / 2$ bucket of chicken carcasses, and another bucket of used horse bedding. Each layer was moistened with water as needed. Finally, both treatments were covered with an approximately 10-12-inch layer of dry wood shavings for vector control. All six piles were approximately 5 feet in height and 8-10 yard ${ }^{3}$ including the cap and base material.

All piles were created with one person operating both the tractor and HM and the time to create all piles, except pile 1, was timed for comparison. In accordance with USDA protocol, two back connect bimetal thermometers $\left(\right.$ Reotemp $\left.{ }^{\circledR}\right)$ were placed 18 inches deep and 36 inches deep in each pile [26]. The thermometers were placed on the east side of piles 1, 3, 4, 6 and the west side of piles 2 and 5 .

Temperatures were recorded manually once a day (Monday-Friday, excluding holidays) for a 30-day period. USDA protocol allows turning of HPAI piles after 14 days if temperature requirements are met, so on day 16 all treatments were turned with the tractor loader by first rolling the pile over to the east and then rolling back to the west to their original location. A 2-gallon bucket sample of the core was taken from both the east and west side of the piles on day 0 , after turning on day 16 , and on day 30 . All pavement was marked with orange spray paint for the start and stop of each pile and sample locations were 5 feet from the edge of the pile markers to avoid sample bias. Samples were screened through a $1 / 2$ inch mesh screen. The remaining material that did not pass through the screen was weighed and recorded. These measurements were referred to as screen weights.
On August 31, 2016, a third treatment, VM, was created including the same feedstock materials as in the HM and CL treatments. However, the VM treatment did not have water added to the mixer or the base layer when first created. These piles were created west of the HM treatment on the paved surface. A base layer was created in the same manner as the previous treatments. One bucket of chicken carcasses, one bucket of used horse bedding, one bucket of wood chips, and one bucket of poultry manure were placed inside a VM (Kuhn Knight Vertical Maxx VT144) and allowed to mix. The VM was used to apply the mix to the top of the horse bedding. Due to the low discharge door on the VM, the first load was applied to the entire length of the base layer rather than as an individual pile. The next two loads were mixed similarly and applied across the length of the base layer again. Finally, the piles were covered with a cap in the same manner as the previous treatments. The VM piles were not as tall as the HM and CL piles but were wider, due to the low discharge door of the VM, and were approximately 3-4 feet tall and a total of 8-10 yard yar $^{3}$ including base and cap.

Thermometers were placed in the VM treatment and temperatures were recorded once daily for a 28-day period as in the HM and CL treatments. The piles were turned in the same manner on day 14 and 28 . On day 14 , the VM replications were split open with the tractor loader and approximately 100 gallons of water was added to the center of the piles due to low moisture content. On day 0 and after turning on day 14 and 28 core compost samples were collected, screened, and weighed as described for the previous treatments.

Screen weight data for each treatment from day 0 and after turning (day 14 or 16 and day 28 or 30) were compared using independent t-tests with Microsoft Excel software. Variances for each data set were calculated and either an equal or unequal variance independent $t$-tests were used depending on the variance ratio between treatments.

\section{Economic calculations}

For each of the treatment methods, the time to create the replications was recorded. The average number of birds per bucket was used to calculate the time it would take to process 200,000 birds with each method. Due to the small scale of our operation, calculations were then extrapolated for larger sized equipment that could handle more birds at the same time. It was assumed that it would take the same amount of time to process the higher amount of birds with larger equipment, more equipment, and an operator for each piece of equipment.

Equipment and cost information was collected from the 2015 HPAI outbreak in Iowa. Information included hourly rates for equipment (including operator, equipment, and fuel), equipment type, number of each piece of equipment and average number of birds processed in a day [25]. 
Cost calculations were made for composting of birds for layer barns based on estimated times for each treatment, equipment numbers and cost information from the Iowa layer farm outbreak [25] and the Iowa State University 2016 Iowa Farm Custom Rate Survey [27], carbon amounts from the treatments, and carbon amounts and costs from recent HPAI outbreak [28]. Based on recommendations from a USDA agricultural economist, a low and high range is provided for changes in supply and demand depending on the availability of equipment, labor, and carbon material in different regions of the country and on the scale of the outbreak [29]. Since data were provided from actual HPAI outbreaks, the high range is 1.25 times the low range, rather than the suggested 1.5 times the normal cost.

\section{Results}

\section{Temperatures}

Both the HM and CL treatment temperatures (Figures-1 and 2, respectively) performed as expected for appropriately formed compost piles. The HM treatment temperatures reached above $131^{\circ} \mathrm{F}$ for both the 18 " and 36" depth by day 4, which was 1 day sooner than the CL treatment at day 5. The HM treatment 36" temperatures were approximately $10^{\circ} \mathrm{F}$ warmer than the CL treatment 36" temperatures during the first 14-day cycle. The temperatures for the VM treatment

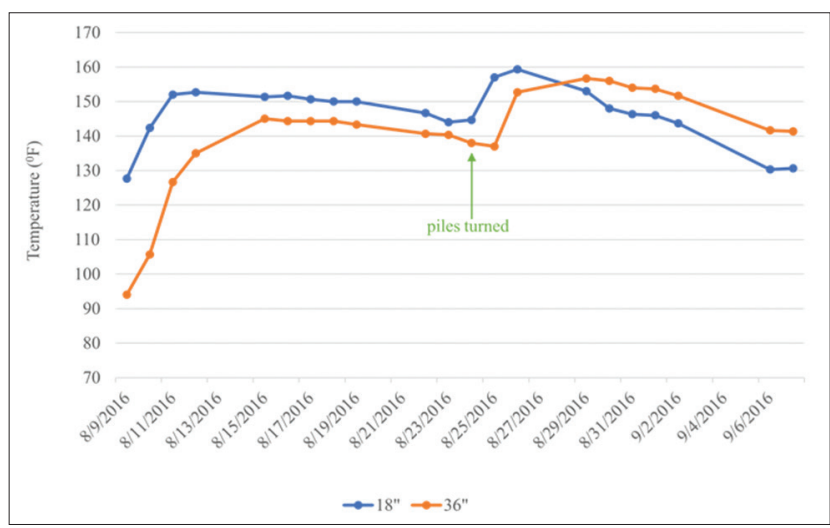

Figure-1: Average temperatures for horizontal mixer treatment.

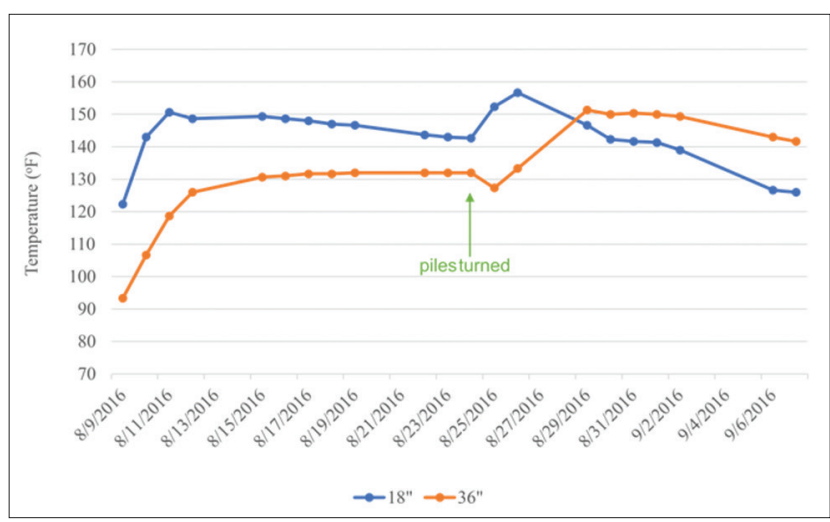

Figure-2: Average temperatures for conventional layering treatment.
(Figure-3) only reached $131^{\circ} \mathrm{F}$ at both the 18 " and 36 " depth for one day after the piles were watered and turned. The VM treatment was significantly dry compared to the other treatments. In addition, the VM piles did not have a sufficient parabolic shape, as it is ideal for composting, due to the low discharge door on the wagon used in our trial. The temperatures for the VM treatment did stay above $110^{\circ} \mathrm{F}$ for most of the treatment trial. The thermometers for the VM treatment were reset on day 12 of the first cycle due to the thermometers sinking too low into the pile and reading close to ground level at 36 " level. The reset resulted in a $10^{\circ} \mathrm{F}$ increase in temperature for the 36 " reading and a $3^{\circ}$ increase at the $18^{\prime \prime}$ reading (Figure- 3 ).

\section{Screen weights}

Screen weights for both the HM and VM treatments significantly declined $(\mathrm{p}=0.09$ and 0.00001 , respectively) in the first 2-week cycle, whereas there was no significant difference in the CL treatment (Figure-4). This was due to the presence of whole birds on day 0 in the CL treatment, and the inability to get a true screen weight value with a small 2-gallon sample size. The 2-gallon sample either had a whole bird or no birds at all depending on where the pile was sampled. The screen weights were significantly higher for the VM treatment on day 0 than for the $\mathrm{CL}$

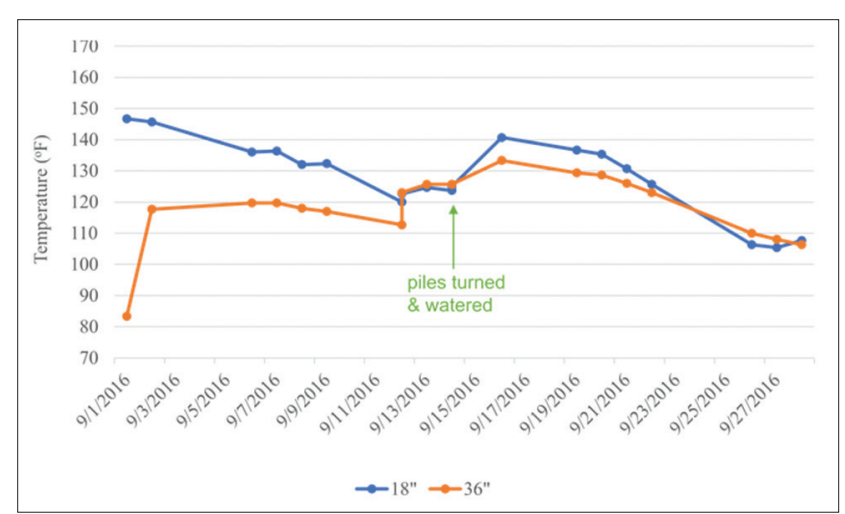

Figure-3: Average temperatures for vertical mixer wagon treatment.

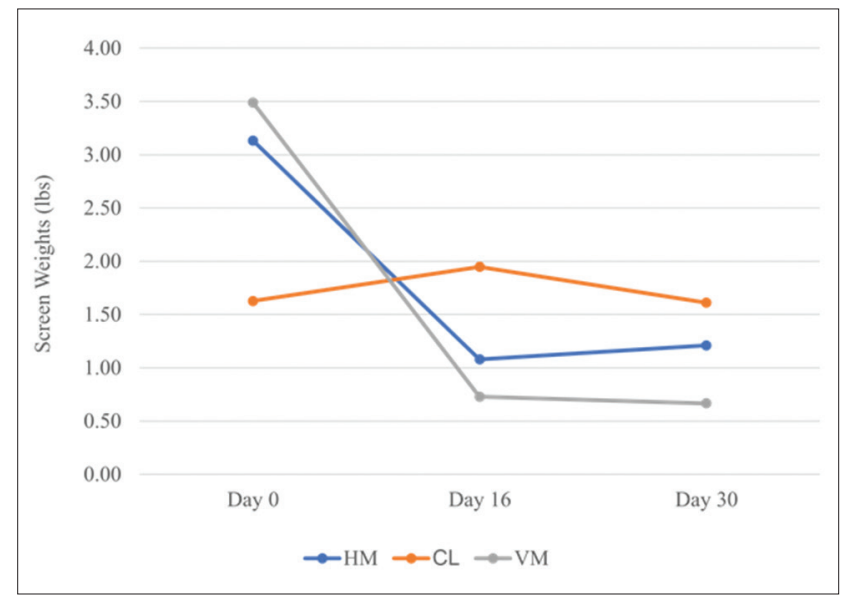

Figure-4: Average screen weights for conventional layering, horizontal mixer and vertical mixer (VM) treatments day 0 , 16*, and 30*. *Actually day 14 and 28 for VM treatment. 
treatment $(p=0.008)$. This is also explained by the presence of whole birds and dry carbon material in the CL treatment and an evenly distributed mixture of bird parts and carbon material in the VM treatment.

At the end of the first 2-week cycle, there was no significant difference between the screen weights for the HM (1.08 lbs.) and the CL (1.95 lbs.) treatments or between the VM $(0.73 \mathrm{lbs}$.) and HM treatments. However, there was a slightly significant difference $(\mathrm{p}=0.10)$ between the VM and CL treatment screen weights. Screen weights on day 16 for the CL treatment had a large variance due to the continued presence of whole birds in some samples and only dry carbon in other samples, in comparison to small variances for both the HM and VM treatments.

By the end of the composting trials, the final screen weights for the VM $(0.67 \mathrm{lbs}$.) treatment were significantly lower than the screen weights for both the HM (1.21 lbs.) and CL (1.61 lbs.) treatments $(p=0.05$ and 0.01 , respectively). There was no significant difference between the HM and the CL treatment screen weights. In the second 2-week cycle, there was no significant change in screen weights for the HM, CL, or VM treatments.

\section{Economic calculations}

Table-1 lists minimal times for the CL, HM, and VM treatments per 254 birds (the average number of birds per bucket load/pile). These times were used to calculate the number of hours it would take to process 200,000 birds based on the small-scale set up in our trials. When calculating the costs for the HM or VM treatment versus the CL treatment in Table-2, the size of equipment and quantity of equipment and operators was scaled up to process more birds in the same amount of time. It was approximated that if two 5 yard $^{3}$ loaders with 2 operators (instead of a $3 / 4$ yard $^{3}$ loader) and at least a 24 yard $^{3}$ mixer wagon (instead of a 15-16 yard $^{3}$ mixer) were used, 1700 laying hens with manure or 3400 laying hens without manure could be processed in the average $15 \mathrm{~min}$.

While the Iowa HPAI outbreak farm used a tub grinder and tebbe manure spreaders, it was assumed that the mixer wagon rates would be similar to the tebbe manure spreader and would take the place of both the tub grinder and manure spreader. This rate assumption seemed reasonable when a local Iowa equipment dealer gave a rental rate of approximately $\$ 80-100 / \mathrm{h}$ for their VMs without fuel and operator costs. The CL method for both layer and turkey farms required at least one additional laborer on the ground due to the tendency for whole birds to roll off the pile and necessitates more labor to replace them and more carbon material to cover them up (Table-2).

For a layer operation outbreak, when using at least a 24 yard $^{3}$ mixer and 2 five yard ${ }^{3}$ loaders, 200,000 layer birds can be processed in $20 \mathrm{~h}$ without manure and $30 \mathrm{~h}$ with manure and costs between $\$ 15,000$ and $\$ 37,256$, depending on supply and demand and the amount of manure that needs to be composted. In comparison, the CL method takes approximately $35 \mathrm{~h}$ to complete and costs between $\$ 20,500$ and $\$ 48,300$ depending on the supply and demand and the amount of manure per 200,000 birds (Table-2).

\section{Discussion}

AI outbreaks in the US have become increasingly more common in the past couple of decades. Due to its severe impacts on food security, international trade, and human health, AI is an important disease that requires thorough surveillance as well as efficient and timely response to eradication. During the most recent outbreak of HPAI in the US from 2014 to 2016, composting and burial were the most common methods of carcass disposal [10]. Due to the size of the outbreak, disposal efforts were challenged by availability of equipment, labor, and carbon material [10]. Bottleneck effects drove up the cost of labor and supplies, and subsequently, the speed of clean-up efforts. As an epizootic disease, it is imperative that efforts are made to improve response and disposal in the future. It is also important that the disposal methods do not pose a risk to biosecurity and environmental pollution and are as economically efficient as possible. While burial may be a less technical and easier solution to carcass disposal than composting, it brings the risk of environmental pollution and, if taken offsite, to biosecurity. Concerns about virus survival with the burial of infected carcasses have also been raised [14]. In contrast, on-site composting carries little risk to biosecurity, is efficient at viral inactivation, poses minimal risk to the environment and creates a useful end-product that can be marketed and utilized. For these reasons, further efforts should be made to improve and reduce the cost of composting methods to encourage its use as the preferred method of carcass disposal during FAD outbreaks.

During the composting trials at the Compost Research and Education Center, the VM treatment had superior tissue breakdown than the CL or the HM treatment and accelerated tissue decomposition. Both the VM and HM treatments had significant decreases in

Table-1: Minimal processing times for $\mathrm{HM}, \mathrm{CL}$, and $\mathrm{VM}$ treatments with 1 ( $3 / 4$ yard ${ }^{3}$ ) loader, 1 tractor operator, 1 mixer and 1 laborer, with manure.

\begin{tabular}{|c|c|c|}
\hline CL & VM (16.3 yard $\left.^{3}\right)$ & HM (15.5 yard $\left.^{3}\right)$ \\
\hline 14 min per 254 birds & 16.22 min per 254 birds & 14.17 min per 254 birds \\
\hline 11,023 min per 200,000 birds & 12,600 min per 200,000 birds & $11,157 \mathrm{~min}$ per 200,000 birds \\
\hline $184 \mathrm{~h}$ per 200,000 birds & $210 \mathrm{~h}$ per 200,000 birds & $186 \mathrm{~h}$ per 200,000 birds \\
\hline
\end{tabular}

CL: Conventional layering, HM: Horizontal mixer, VM: Vertical mixer 
Table-2: Economic estimates for $\mathrm{CL}$ and mixer wagon methods for layer hens.

\begin{tabular}{|c|c|c|c|c|}
\hline \multirow[t]{2}{*}{ Methodology Used } & \multicolumn{4}{|c|}{ Cost per 200,000 birds } \\
\hline & \multicolumn{2}{|c|}{ No manure } & \multicolumn{2}{|c|}{ With manure } \\
\hline \multicolumn{5}{|l|}{ Mixer wagon method } \\
\hline 2 days without manure, 3 days with manure ( 10 hrs/day) per 200,000 birds & Low & High* & Low & High* \\
\hline \multicolumn{5}{|l|}{ Equipment (fuel, equipment, operator included) } \\
\hline 5 yard $^{3}$ wheel loader making base/cap $(\$ 125 / \mathrm{h})$ & $\$ 2,500$ & $\$ 3,125$ & $\$ 3,750$ & $\$ 4,688$ \\
\hline 5 yard $^{3}$ wheel loader adding birds, carbon, manure to mixer $(\$ 125 / \mathrm{h})$ & $\$ 2,500$ & $\$ 3,125$ & $\$ 3,750$ & $\$ 4,688$ \\
\hline 1 tractor with mixer $(\$ 180 / \mathrm{h})$ & $\$ 3,600$ & $\$ 4,500$ & $\$ 5,400$ & $\$ 6,750$ \\
\hline \multicolumn{5}{|l|}{ Labor } \\
\hline 1 laborer on the ground $(\$ 20 / \mathrm{h})$ & $\$ 400$ & $\$ 500$ & $\$ 600$ & $\$ 750$ \\
\hline 1 foreman $(\$ 40 / h)$ & $\$ 800$ & $\$ 1,000$ & $\$ 1,200$ & $\$ 1,500$ \\
\hline \multicolumn{5}{|l|}{ Carbon material } \\
\hline $600-1180 \operatorname{yard}^{3}\left(\$ 9-16 /\right.$ yard $\left.^{3}\right)$ & $\$ 5,400$ & $\$ 9,600$ & $\$ 10,620$ & $\$ 18,880$ \\
\hline Total cost & $\$ 15,200$ & $\$ 21,850$ & $\$ 25,320$ & $\$ 37,256$ \\
\hline \multicolumn{5}{|l|}{ CL method } \\
\hline 3.5 days $(10 \mathrm{~h} /$ day $)$ per 200,000 birds & Low & High* & Low & High* \\
\hline \multicolumn{5}{|l|}{ Equipment (fuel, equipment, operator included) } \\
\hline 1 track skid loader making base/cap $(\$ 100 / \mathrm{h})$ & $\$ 3,500$ & $\$ 4,375$ & $\$ 3,500$ & $\$ 4,375$ \\
\hline 1 track skid loader layering carbon/litter $(\$ 100 / \mathrm{h})$ & $\$ 3,500$ & $\$ 4,375$ & $\$ 3,500$ & $\$ 4,375$ \\
\hline 1 track skid loader layering birds $(\$ 100 / \mathrm{h})$ & $\$ 3,500$ & $\$ 4,375$ & $\$ 3,500$ & $\$ 4,375$ \\
\hline 1 track skid loader layering manure $(\$ 100 / \mathrm{h})$ & & & $\$ 3,500$ & $\$ 4,375$ \\
\hline \multicolumn{5}{|l|}{ Labor } \\
\hline 2 laborers on the ground $(\$ 20 / \mathrm{h})$ & $\$ 800$ & $\$ 1,000$ & $\$ 800$ & $\$ 1,000$ \\
\hline 1 foreman $(\$ 40 / \mathrm{h})$ & $\$ 800$ & $\$ 1,000$ & $\$ 800$ & $\$ 1,000$ \\
\hline \multicolumn{5}{|l|}{ Carbon material } \\
\hline $900-1800$ yard $^{3}\left(\$ 9-16 /\right.$ yard $\left.^{3}\right)$ & $\$ 8,100$ & $\$ 14,400$ & $\$ 16,200$ & $\$ 28,800$ \\
\hline Total cost & $\$ 20,200$ & $\$ 29,525$ & $\$ 31,800$ & $\$ 48,300$ \\
\hline
\end{tabular}

Based on recorded times and carbon amounts for each method at Highmoor Farm, costs from HPAI outbreak farm in Iowa in 2015 [25] and carbon amounts and costs from HPAI influenza outbreak farms [28]. *High estimate is 1.25 times the low end to allow for changes in supply and demand. HPAI=High pathogenic avian influenza, $C L=C o n v e n t i o n a l$ layering

particle size from the start of the trial to the end of the first 2-week cycle. Smaller particle size and accelerate tissue decomposition could greatly increase the value of the final compost product and deem the material more acceptable to land owners for field application.

While the HM treatment had superior peak temperatures during the first 2-week cycle, the VM treatment did not perform as well for temperature. This can be explained by inadequate moisture content and poor windrow formation. In addition, pile thermometers sunk too low in the pile and were reset on day 12 causing a significant increase in temperature at the 36 " level. Higher peak temperatures for the first cycle could have been missed due to improper thermometer placement. One challenge with the VM was the discharge door was too low to create a sufficiently high enough pile. This can be remedied with the addition of a belt driven chute that can discharge material up to 6 feet tall. Alternatively, a loader could be used to push the piles higher. Despite these challenges, tissue breakdown was superior. While temperatures for this method did not meet the $131^{\circ} \mathrm{F}$ for 3 consecutive days' standard set by the USDA composting protocol, it did meet $110^{\circ} \mathrm{F}$ for 10 consecutive days for both cycles and temperatures were more than adequate to kill the virus. Other factors besides heat during composting have been shown to be important in virus inactivation as well $[22,23]$. The temperatures in all treatments in this study were consistently adequate for efficient virus inactivation within compost piles according to published research [18,19,21].

The VM and HM treatments also support shortening of the current requirement of a 4-week composting cycle. The data from the HM and especially the VM treatment showed a significant difference in particle size in the first 2 weeks, but no difference in the second 2-week cycle. Since virus inactivation has been demonstrated to occur within $24 \mathrm{~h}$ at temperatures as low as $25^{\circ} \mathrm{C}\left(77^{\circ} \mathrm{F}\right)$ in manure [19] and as low as $42^{\circ} \mathrm{C}\left(107^{\circ} \mathrm{F}\right)$ in compost [21], a 2 week cycle with turning of the piles after 7 days to ensure homogeneous temperatures and mixing should be ample time to achieve neuralization of the virus. While shortening of the composting cycle may not have direct effects on the cost of carcass disposal, it could have an immense impact on reducing the opportunity costs to producers if their barns or fields were only occupied for half the time. This could accelerate the cleaning and disinfecting of the barns, allowing producers to restock their flocks sooner and encourage producers to choose composting over burial. While the compost product would not be ready for field application as a soil amendment, it could be safely moved to an approved storage site without biosecurity risk.

Even without the reduction in opportunity cost with a shorter composting cycle, the economic calculations in this project support the use of a mixer wagon for carcass composting. The reduced amount 
of carbon material and manual labor required, as well as the increased speed with larger equipment, make it an economical choice. A similar method of particle reduction size and windrow construction was achieved during an outbreak in Iowa and not only proved to be effective but also economical [25]. Other forms of equipment, such as the tub grinder and tebbe manure spreaders used in Iowa, could be considered, depending on availability and cost. In large agricultural regions, such as Iowa, equipment such as feed mixers may be more available than in other regions of the country. In addition, the higher economic value of the final compost product with the mixer wagon method could further decrease costs with the sale of the composting material and the decreased storage time until the product is utilized.

During the 2014-2016 AI outbreak, reports of prolonged times between depopulation and carcass disposal have been reported due to shortages in labor, equipment, and carbon sources during the height of the outbreak $[25,29]$. Several lessons can be learned from this, including the importance of securing equipment, labor, carbon sources, and other supplies for each state before an outbreak. These preparations not only help ensure adequate resources are available and efficiently acquired but can also help reduce hikes in cost if contracts are already in place. Reduced costs could make composting even more economically feasible and reduce the amount of facilities that choose burial as their method of disposal. Poultry producers should be encouraged to develop emergency plans of their own as well.

The 2016 USDA APHIS protocol for carcass composting of AI flocks does not currently support the use of mixing or grinding equipment for carcass disposal due to the potential risk of virus aerosolization. This project did not address aerosolization concerns with the VM or HM and should be investigated in future studies. In addition, due to the small sample size of this study, a larger trial and sample size could provide more information. A larger trial with a VM wagon with a 6-foot discharge chute and adequate moisture could improve the temperature profile and efficiency and provide more support for its use during an outbreak.

\section{Conclusion}

Particle size reduction and mixing improve and accelerates degradation rates of poultry carcasses in compost. This study indicates that a vertical or HM wagon is an economical method for processing poultry carcasses. Other equipment that achieves particle size reduction and mixing should be considered depending on equipment availability in different regions of the country. Besides a reduction in the direct costs of carcass composting with efficient handling of carcasses, manure, and carbon material, reduced opportunity costs for producers could be achieved with a shorter composting cycle based on current research on AI virus stability in compost and manure. Direct cost reductions for composting could also be achieved if states and producers planned for equipment, labor, carbon material, and other supplies before an outbreak. These reductions in direct and opportunity costs could encourage more producers to select composting as the means for carcass disposal over burial, which can have additional costs associated with groundwater contamination and prolonged virus inactivation as well as reduced value of property.

\section{Authors' Contributions}

JEK and MH designed, set up, and collected data for the experiment. JEK analyzed the data and wrote the manuscript. JEK and MH read and approved the final manuscript. All authors read and approved the final manuscript.

\section{Acknowledgments}

In-kind funding of equipments, supplies, and facilities was provided by the University of Maine Cooperative Extension and Maine Compost Team.

\section{Competing Interests}

The authors declare that they have no competing interests.

\section{References}

1. WHO. Avian Influenza: Fact Sheet; 2014. Available from: http://www.who.int/mediacentre/factsheets/avian_influenza/en/\#. [Last cited on 2016 Oct 10].

2. Swayne DE, editor. Avian Influenza. Hoboken: Wiley; 2009.

3. Institute CWM. Summary of Avian Influenza. Cornell University, Sciences DoCaS; Report. January; 2008.

4. Ungchusak K, Auewarakul P, Dowell SF, Kitphati R, Auwanit W, Puthavathana P, et al. Probable person-to-person transmission of avian influenza A (H5N1). N Engl J Med 2005;352:333-40.

5. CDC, CfDCaP. Transmission of Avian Influenza Virus between Animals and People; 2015. Available from: http:// www.cdc.gov/flu/avianflu/virus-transmission.htm. [Last updated on 2015 Oct 12; Last cited on 2016 Oct 19].

6. WHO. Cumultative Number of Confirmed cases for Avian Influenza A (H5N1) Reported to WHO, 2003-2016; 2016.

7. USDA. In: Service NAS, editor. Census of Agriculture Highlights: Poultry and Egg Production. US: USDA; 2015. p. 2.

8. Service USDoAER. Poultry and Eggs Overview; 2016. Available from: http://www.ers.usda.gov/topics/animal-products/poultry-eggs.aspx. [Last updated on 2016 Oct 19; Last cited on 2016 Oct 30].

9. Johansson RC, Preston WP, Seitzinger AH. Government spending to control highly pathogenic avian influenza. Choices: The Magazine of Food, Farm, and Resource Issues. Vol. 31. USA: Agricultural and Applied Economic Association, Utah State University; 2016.

10. Johnson KK, Seeger RM, Marsh TL. Local economies and highly pathogenic avian influenza. Choices: The Magazine of Food, Farm, and Resource Issues. Vol. 31 USA: Agricultural and Applied Economic Association, Utah State University; 2016

11. Greene JL. Update on the Highly-Pathogenic Avian Influenza Outbreak of 2014-2015. Congressional Research Service; 2015. p. 1-18.

12. Swayne D, Akey B. Avian influenza control strategies in the 
United States of America. Avian Influenza, Prevention and Control. Dordrecht: Springer; 2005. p. 113-30.

13. Blake JP, Donald J. Alternatives for the disposal of poultry carcasses. Poult Sci 1992;71:1130-5.

14. Graiver DA, Topliff CL, Kelling CL, Bartelt-Hunt SL. Survival of the avian influenza virus (H6N2) after land disposal. Environ Sci Technol 2009;43:4063-7.

15. Bendfeldt ES, Peer RW, Flory GA. In-house composting as a rapid response to avian influenza. BioCycle 2006;47:38-42.

16. Flory GA, Peer RW, Richmond C. Initial Evaluation of the Effectiveness of On-Farm Composting for the Disposal of Market-Aged Turkey Carcasses Resulting from an Outbreak of Low Pathogenic AI (H5N2) in West Virginia; 2007. Available from: http://www.deq.virginia. gov/Portals/0/DEQ/Water/VirginiaPollutionAbatement/ InitialEvaluationOfOnFarmCompostingInWestVirginia. pdf. [Last updated on 2007 Jun 27; Last cited on 2016 Oct 18].

17. Flory GA, Peer RW. Verification of poultry carcass composting research through application during actual avian influenza outbreaks. ILAR J 2010;51:149-57.

18. Lu H, Castro AE, Pennick K, Liu J, Yang Q, Dunn P, et al. Survival of avian influenza virus H7N2 in SPF chickens and their environments. Avian Dis 2003;47:1015-21.

19. Chumpolbanchorn K, Suemanotham N, Siripara N, Puyati B, Chaichoune K. The effect of temperature and UV light on infectivity of avian influenza virus (H5N1, Thai field strain) in chicken fecal manure. Southeast Asian J Trop Med Public Health 2006;37:102-5.
20. Elving J, Emmoth E, Albihn A, Vinnerås B, Ottoson J. Composting for avian influenza virus elimination. Appl Environ Microbiol 2012;78:3280-5.

21. Senne DA, Panigrahy B, Morgan RL. Effect of composting poultry carcasses on survival of exotic avian viruses: Highly pathogenic avian influenza (HPAI) virus and adenovirus of egg drop syndrome-76. Avian Dis 1994;38:733-7.

22. Glanville TD, Richard TL, Harmon JD, Reynolds DL, Ahn HK, Akine S. Composting livestock mortalities. (Iowa department of natural resources). BioCycle 2006;47:42.

23. Guan J, Chan M, Grenier C, Wilkie DC, Brooks BW, Spencer JL. Survival of avian influenza and Newcastle disease viruses in compost and at ambient temperatures based on virus isolation and real-time reverse transcriptase PCR. Avian Dis 2009;53:26-33.

24. Tablante NL, Malone GW, editors. Controlling Avian Influenza Through In-House Composting of Depopulated Flocks: Sharing Delmarva's Experience. Proceedings of 2006 National Symposium on Carcass Disposal; 2006.

25. Elbert G. Phone Interview. October 20, 2016.

26. Miller LP, Flory GA, Peer RW, Benfeldt ES, Hutchinson ML, King MA, et al. FY2016 HPAI Response: Mortality Composting Protocol for Avian Influenza Infected Flocks. USDA APHIS. 2016. p. 31.

27. Plastina A, Johanns A, Erwin J. Iowa Farm Custom Rate Survey. Iowa State University, Outreach Ea; 2016 March 2016. Report No, Contract No. A3-10; 2016.

28. Payne JB. Email Interview. September 6, 2016.

29. Johnson KK. Phone Interview. September 13, 2016. 